\title{
Some Weeds Community Percent in Response to Pumice Application on Soil under Water Stress Conditions
}

\author{
Mehdi Nasiri" ${ }^{\# 1}$, Davoud Zarehaghi ${ }^{\# 2}$, Mohammad Reza Neyshabouri ${ }^{\# 3}$ \\ \# Soil Science Department, College of Agriculture, University of Tabriz, Iran \\ E-mail: ${ }^{1}$ M_nasiry65@yahoo.com, ${ }^{2}$ davoudhaghi@tabrizu.ac.ir, ${ }^{3}$ neyshmr@yahoo.com
}

\begin{abstract}
A factorial experiment (using RCBD design) with three replications was conducted in 2014 at the University of TabrizIran, in order to determine the effects of pumice application (P1, P2, P3 and P4: control, 30, 60 and 90 tons per ha) on soil and water stress (I1, I2 and I3: $100 \%, 70 \%$ and $50 \%$ water requirement calculated from class $\mathrm{A}$ pan, respectively) on dominante weeds community percent. Results showed that community percent of weed species changed as a result of water stress and pumice application on soil. Distributions of Chenopodium album and Malva sylvestris were sensitive to water stress but, Amaranthus retroflexus and Solanum nigrum were neutral to water stress. In contrast, Amaranthus retroflexus, Cardaria draba, Setaria viridis, Sisymbrium irio, Xanthium strumarium, Convolvulus arvensis and Salsola rigida distribution were resistant to water stress. Community percent of Chenopodium album as sensitive species to water stress and Salsola rigida as resistance species to water stress positively affected by pumice application especially under water stress condition. Amaranthus retroflexus, Xanthium strumarium and Convolvulus arvensis were positively affected by pumice application under well and limited water supply conditions. In contrast, Cardaria draba, Sisymbrium irio and Solanum nigrum negatively affected by pumice under water stress and it had positive effect on community of these species under well watering conditions. Thus, application of pumice and water stress are two factors which change weed community precent.
\end{abstract}

Keywords - Community percent; Pumice; Water stress; Weed species

\section{INTRODUCTION}

Crop production is mainly dependent on ecological and soil conditions. Iran is located on a dry climate with hot summer and cold winter [1]. About 10 percent of the Iran's cultivated areas have more than $500 \mathrm{~mm}$ rainfall over the years and the rest have to be watered for the plants growth [2]. Therefore, according to geographical location and topographic conditions, Iran has always been faced with drought over the last centuries. Plants both in natural and agricultural conditions are frequently exposed to environmental stresses. According to Hayat and Ali [3], water stress is a limiting factor for crop growth in arid and semi-arid regions.

Pumice is one of the super absorbents, being a type of extrusive volcanic rock, produced when lava with a very high content of water and gases is extruded from a volcano and serves to open up the mix and reduce the moisture retention properties of the soil [4]. Pumice particles of $2-5 \mathrm{~mm}$ in diameter in natural conditions are responsible of the higher moisture holding capacity of sandy soils pomaceous origin [5], because they have a water storage capacity of $68 \%$, of which $80 \%$ is readily available to plants [6]. It is also suggested, that pumice can be used as promoter of retention of moisture in the soil and increasing efficiency in water use at low cost. In this regard, studies conducted without crop in sandy substrates of sedimentary origin with $30 \%$ of industrial pumice waste $(2.38-3.35 \mathrm{~mm}$ in diameter) found increased water-holding capacity of the substrate $44 \%$, of which, 56\% was available [7]. In this sense, the materials pomaceous discarded by blue jeans factories after the fabric softening and fuzz, become important in arid and semiarid regions of the world, where problems with water scarcity are found [8].

The application of super absorbent polymer has a significant impact in reducing drought stress effects and to improve plants yield and stability in agriculture production [9]. Woodhouse and Johnson [10] reported that hydro-absorbents can play a crucial role in germination rates because of improving water accessibility. Johnson and Piper [11] found that fruit quality was better using polymers in the growing media as water stress reduced during the growth cycle. Application of hydrogel at the rate of $2 \mathrm{~g} / \mathrm{kg}$ increased the water holding potential of sand from $171 \%$ to $402 \%$ [12].

Management factors which affect the composition of the weed flora include tillage, water control, soil fertility, crop rotations, sowing time and methods, and herbicide use [13]. Water is the most important environmental factor 
in the habitat, with a marked morphological expression in the plant. The total water available in a location is related to both the initial supply with losses by runoff, evaporation and transpiration. The seasonal distribution of water is akey factor in weed distribution, since sometimes its scarcity at critical stages of the plant leads to lack of reproduction and survival. Climate factors, soil factors, human factors and technological factors change weed community in field. Thus, the objective of the present study was to determine the effects of pumice and water stress in soil on some weeds community percent.

\section{MATERIALS AND METHODS}

A factorial experiment (using RCBD design) with three replications was conducted in 2014 at the Research Farm of the Faculty of Agriculture, University of Tabriz, Iran (latitude $38.05^{\circ} \mathrm{N}$, longitude $46.17^{\circ} \mathrm{E}$, altitude $1360 \mathrm{~m}$ sea level), in order to determine the combined effects of pumice application on the soil surface and water stress on some weeds community percent. One factor was irrigation treatments (I1, I2 and I3: $100 \%, 70 \%$ and 50\% water requirement based on class A pan, respectively) and another factor was pumice levels (P1, P2, P3 and P4: control, 30, 60 and 90 tons per ha).

Different pumice levels after passing from $8 \mathrm{~mm}$ sieve, applied to the experiment plots $\left(2.5 \times 2 \mathrm{~m}^{2}\right)$. Ten weeds species (Chenopodium album, Amaranthus retroflexus, Cardaria draba, Setaria viridis, Sisymbrium irio, Xanthium strumarium, Convolvulus arvensis, Salsola rigida, Solanum nigrum and Malva sylvestris) community percent was measured at six stages by a wooden frame $(100 \mathrm{~cm} \times 50 \mathrm{~cm})$. At the end of enumeration, different weed species sampled and their fresh weight was determined. Then, the samples were dried in an oven at $80^{\circ} \mathrm{C}$ for 24 hours and dry weight of each treatment at each replicate was determined.

All the data were analyzed on the basis of experimental design, using SPSS software. The means of each trait were compared according to Duncan's multiple range test at $\mathrm{P} \leq 0.05$. Excel software was used to draw figures.

\section{RESULTS AND DISCUSSION}

Chenopodium album was one of the dominate weed species in the field. Community of this weed species significantly decreased with increasing water stress under all levels of pumice application. Under I1 treatment, maximum percent of Chenopodium album community was showed in plots with non-treated by pumice, followed by P2, P3 and P4, respectively. The weed community under $\mathrm{I} 2$ was similarly to I1, but there was no difference in weed community under P3 and P4. Under severe water stress, the community of Chenopodium album between different pumice levels was not significant, as in final stage of sampling this weed community under P2 and P4 was more than control treatment (Fig. 1).

Amaranthus retroflexus community percent increased with application of pumice under I1 and I3. Maximum community of this weed was showed from plots with applied with P2, followed by P3, P1 and P4 under I1 and I3. Amaranthus retroflexus distributions under I2 with non- pumice application was the most in comparsion to other treatments (Fig. 2).

Cardaria draba community at the first and at the end stages of sampling was lower than intermediate stages. This weed distribution under I2 was more than I1 and I3. Plots that treated by $\mathrm{P} 4$ had more community of Cardaria draba under I1. Difference in Cardaria draba community during different stages of sampling under control treatments was less than pumice application treatments. Under I1, the lowest Cardaria draba community was obtained from P2. Under I2, the most and the lowest Cardaria draba community was showed from P3 and P4, respectively. However under I3, non-treated plots had more community of this weed species in comparison to other treatments. This weed species was only sampled at the stage of two in P3 treated plots under I3 (Fig. 3).

Setaria viridis distribution was increased with increasing water stress. This weed in P2 during all of the sampling stages was lower than those of other pumice treatments under I1. Maximum community of this weed occured under P1 (except first sampling). Setaria viridis community under water stress conditions (I2 and I3) was similar, as maximum and minimum distributions during all stages of sampling were obtained from P2 and P4, respectively (Fig. 4).

Sisymbrium irio distribution was increased with increasing water stress. Under I1 and I2, maximum community of this weed was showed in P2, followed by P1, P4 and P3, respectively. However, under I3, non-application of pumice plots had more community of this weed. P2 and $\mathrm{P} 4$ during the $1^{\text {st }}, 2^{\text {nd }}$ and $3^{\text {rd }}$ stages of sampling had similar community of this weed but, during the $4^{\text {th }}$ to $6^{\text {th }}$ stages of sampling, the community of Sisymbrium irio with P4 was more than P2 (Fig. 5).

Xanthium strumarium had less distribution in comparison to some other weed species. This weed species was only showed under I1 with P3 and at stages of five under I2 with P2. Malva sylvestris occurred only under I1 with application of P2 and at stages of two with P1 (Fig. 6).

Convolvulus arvensis community percent under I1 was observed in plots with P3 during two stages of sampling. However, this weed species in plots that treated with $\mathrm{P} 4$ was showed during four stages of sampling. Convolvulus arvensis distribution under $\mathrm{I} 2$ was recorded in plots with $\mathrm{P} 1$ and $\mathrm{P} 2$. In contrast, under I3 the community of this weed was more than I1 and I2. Plots that applied with P2 had more community of this weed species, followed by P3, P1 and P4, respectively. Similarly under all water conditions, intermediate stages had more community of this weed species in comparison to the first and the end stages of sampling (Fig. 7).

Salsola rigida community increased with increasing water stress. Distribution of this weed species under all water condition was more during three stages of sampling. Under I1, this weed species was only recorded from plots without pumice application. Under 12 maximum community of this weed was showed from P2 and P4. However, under I3, P1 and P2 had more community of Salsola rigida (Fig. 8).

Solanum nigrum community was less in comparison to other weed species. However, community of this weed increased as a result of water stress. Under I1, this weed was 
only recorded from P3, but under I2 was only showed with P1 and under I3 was recorded from P1, P2 and P3 (Fig. 9).

Water stress and application of pumice in soil had significant effects on fresh and dry weight of some weed species. Fresh weight of Chenopodium album, Amaranthus retroflexus, Setaria viridis, Sisymbrium irio and Salsola rigida significantly decreased with increasing pumice levels. Fresh weight of these weed species under P3 and P4 was similar (Table I).
Dry weight of Chenopodium album, Amaranthus retroflexus and Setaria viridis was also affected by pumice application and this trait significantly reduced as pumice levels increased.

Fresh weight of Chenopodium album and Setaria viridis and dry weight of Amaranthus retroflexus significantly decreased with increasing water stress (Table II).

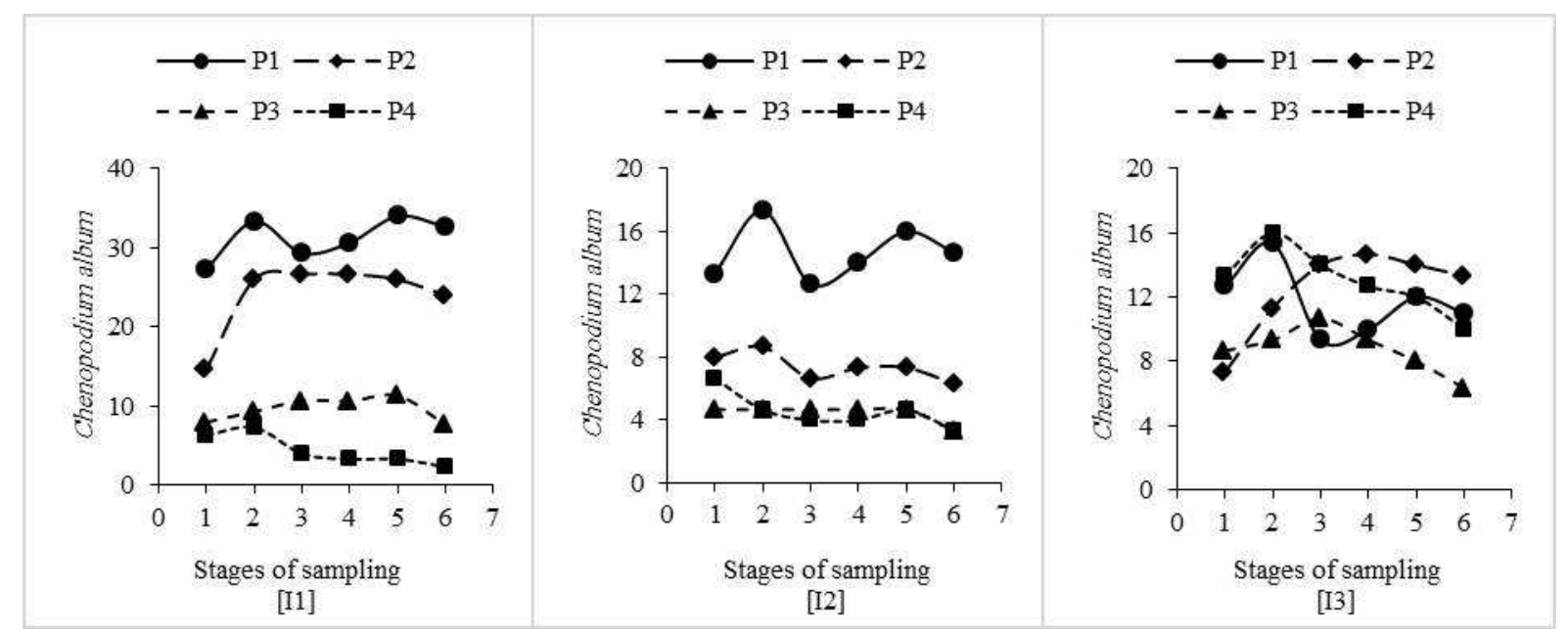

Fig. 1. Chenopodium album community in response to different levels of pumice application and water stress.

I1, I2 and I3: 100\%, 70\% and 50\% water requirement calculated from class A pan, respectively.

P1, P2, P3 and P4: control, 30, 60 and 90 tons per ha.

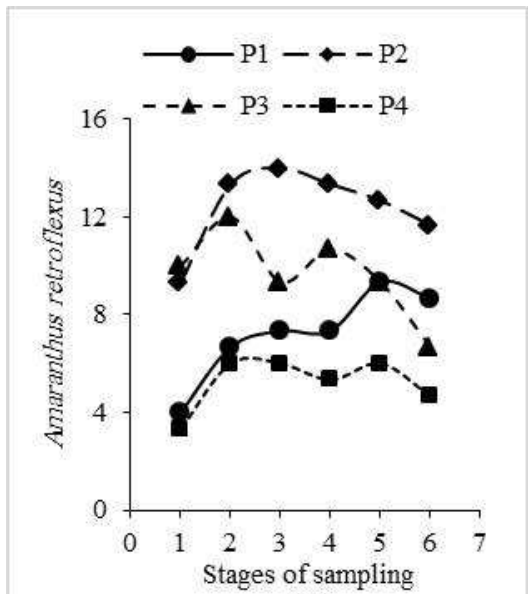

[I1]

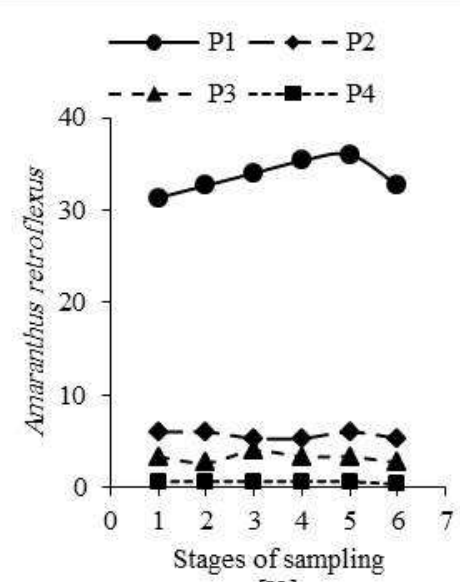

[I2]

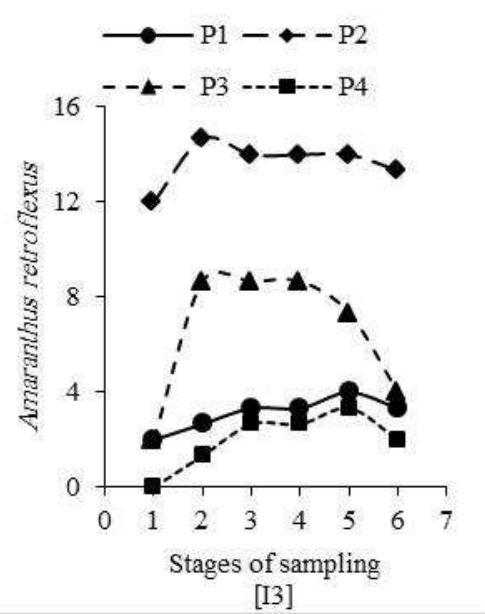

[I3]

Fig. 2. Amaranthus retroflexus community in response to different levels of pumice application and water stress.

I1, I2 and I3: 100\%, 70\% and 50\% water requirement calculated from class A pan, respectively.

P1, P2, P3 and P4: control, 30, 60 and 90 tons per ha. 


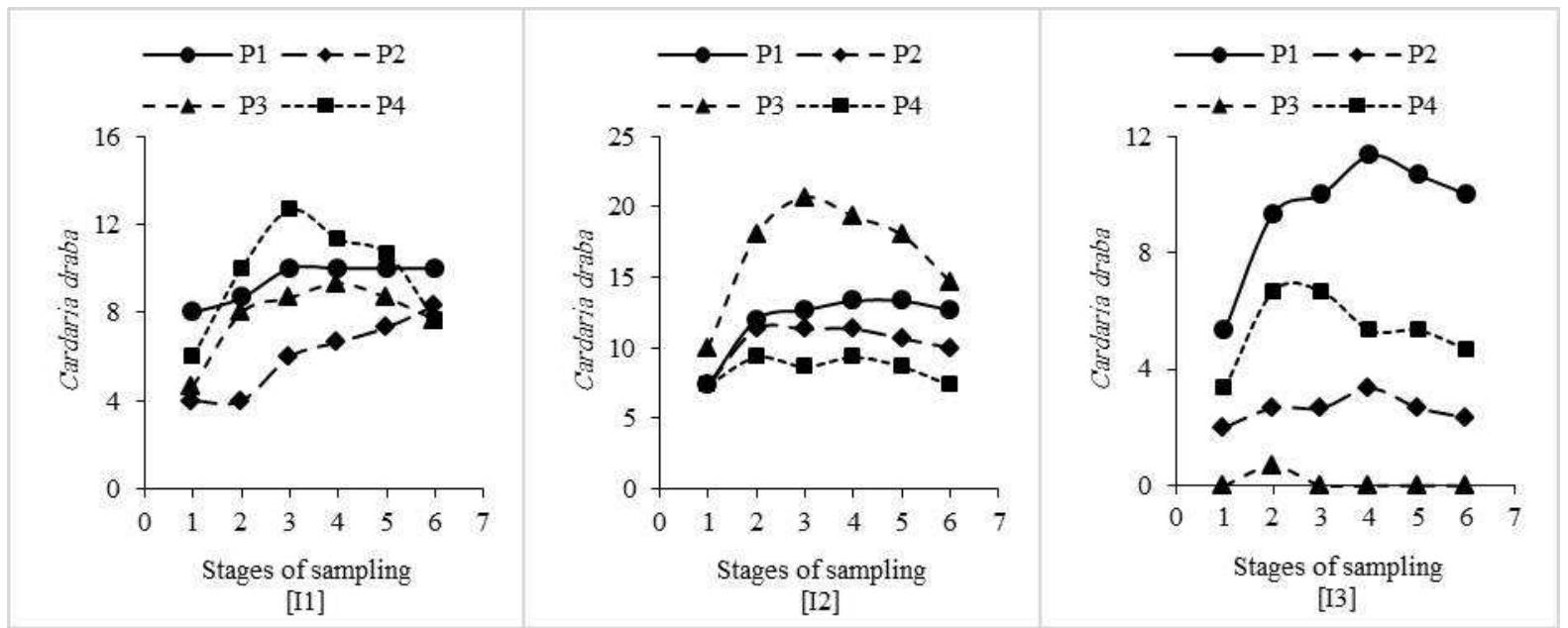

Fig. 3. Cardaria draba community in response to different levels of pumice application and water stress.

I1, I2 and I3: $100 \%, 70 \%$ and $50 \%$ water requirement calculated from class A pan, respectively.

P1, P2, P3 and P4: control, 30, 60 and 90 tons per ha.

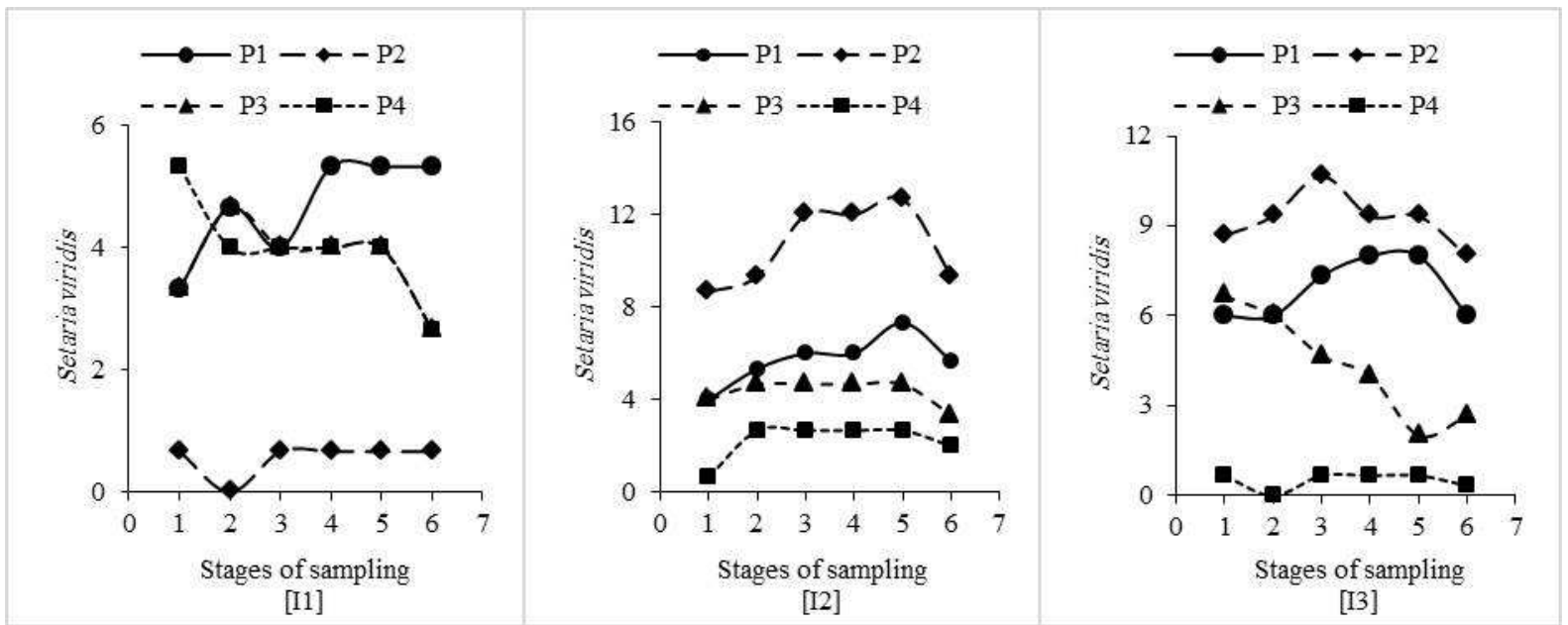

Fig. 4. Setaria viridis community in response to different levels of pumice application and water stress.

I1, I2 and I3: 100\%, 70\% and 50\% water requirement calculated class from A pan, respectively.

P1, P2, P3 and P4: control, 30, 60 and 90 tons per ha.

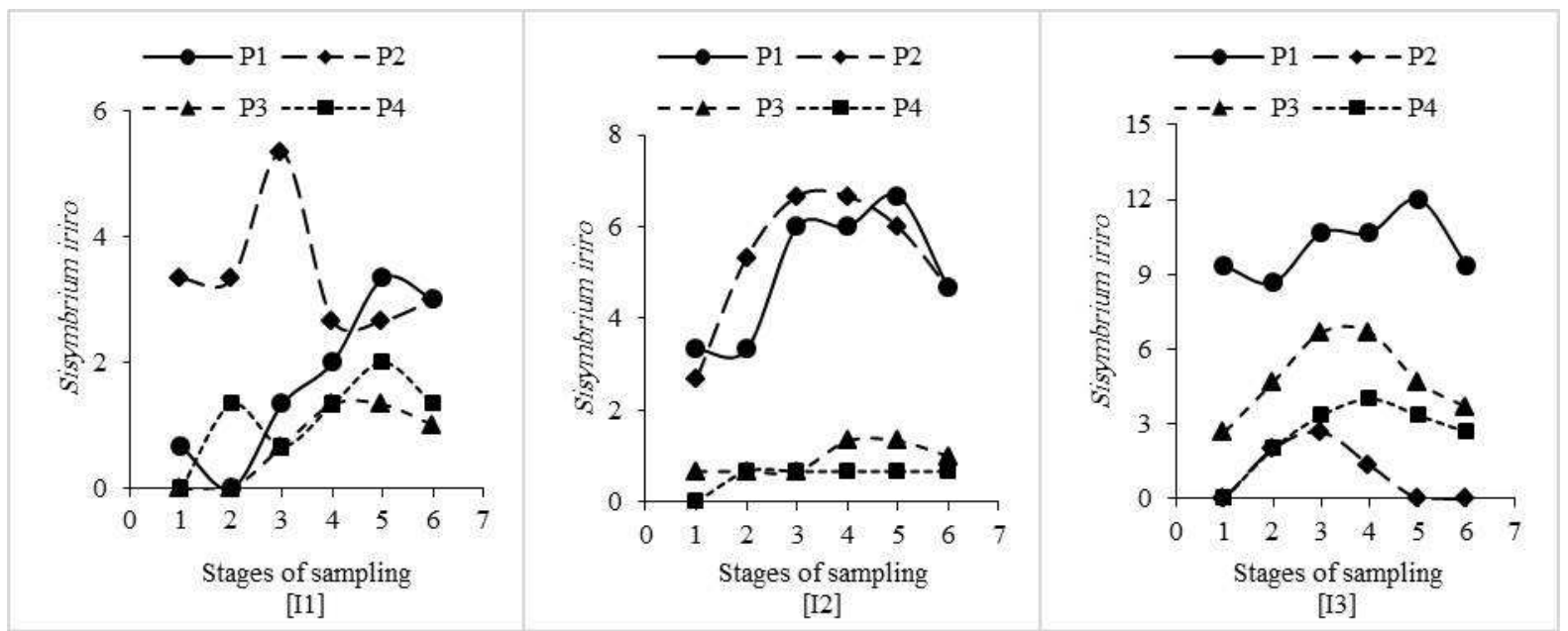

Fig. 5. Sisymbrium irio community in response to different levels of pumice application and water stress.

I1, I2 and I3: 100\%, 70\% and 50\% water requirement calculated from class A pan, respectively.

P1, P2, P3 and P4: control, 30, 60 and 90 tons per ha. 


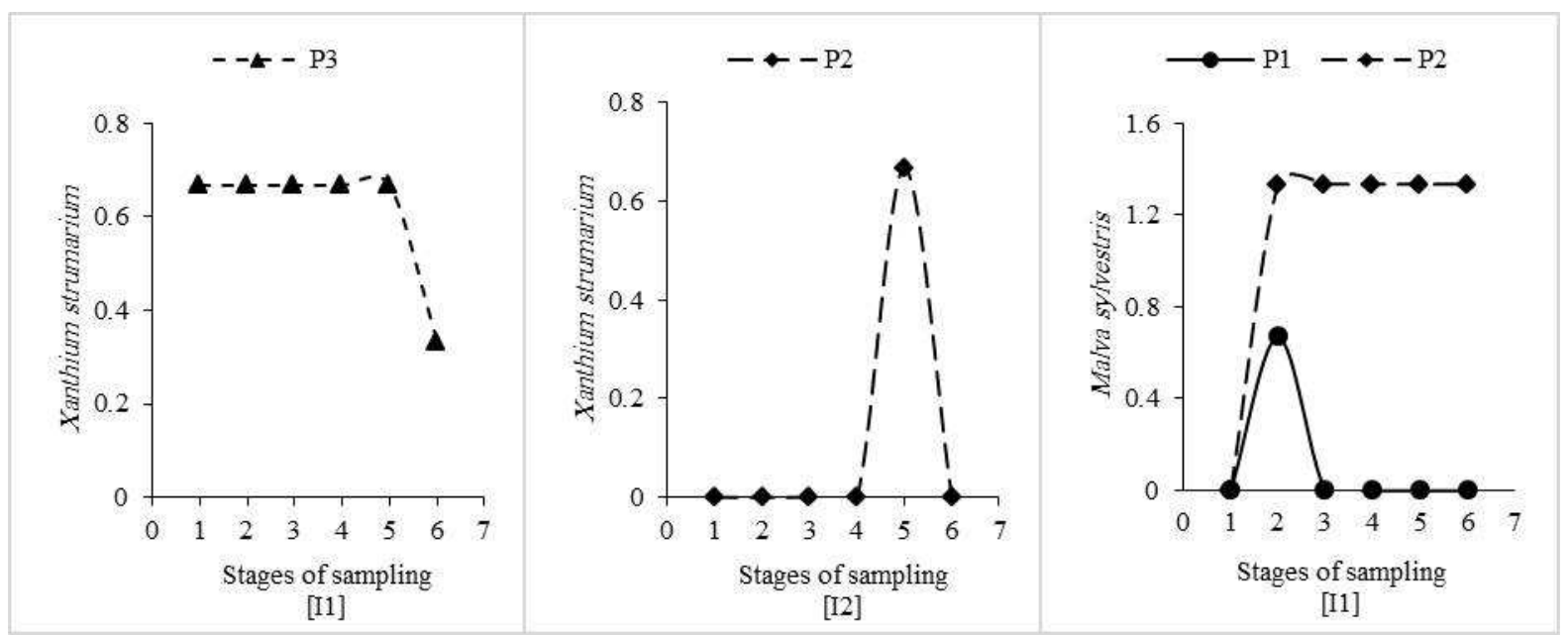

Fig. 6. Xanthium strumarium and Malva sylvestris community in response to different levels of pumice application and water stress. I1, I2 and I3: 100\%, 70\% and 50\% water requirement calculated from class A pan, respectively.

P1, P2, P3 and P4: control, 30, 60 and 90 tons per ha.

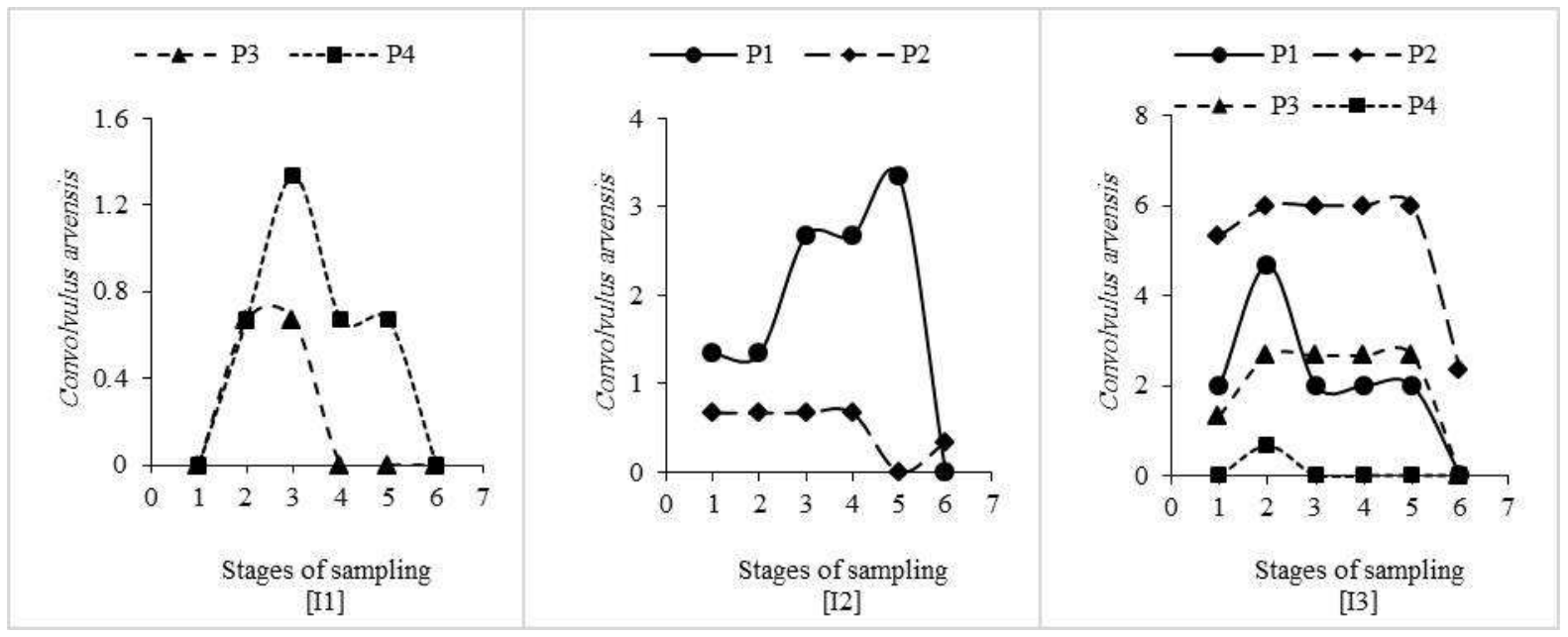

Fig. 7. Convolvulus arvensis community in response to different levels of pumice application and water stress.

I1, I2 and I3: 100\%, $70 \%$ and 50\% water requirement calculated from class A pan, respectively.

P1, P2, P3 and P4: control, 30, 60 and 90 tons per ha.

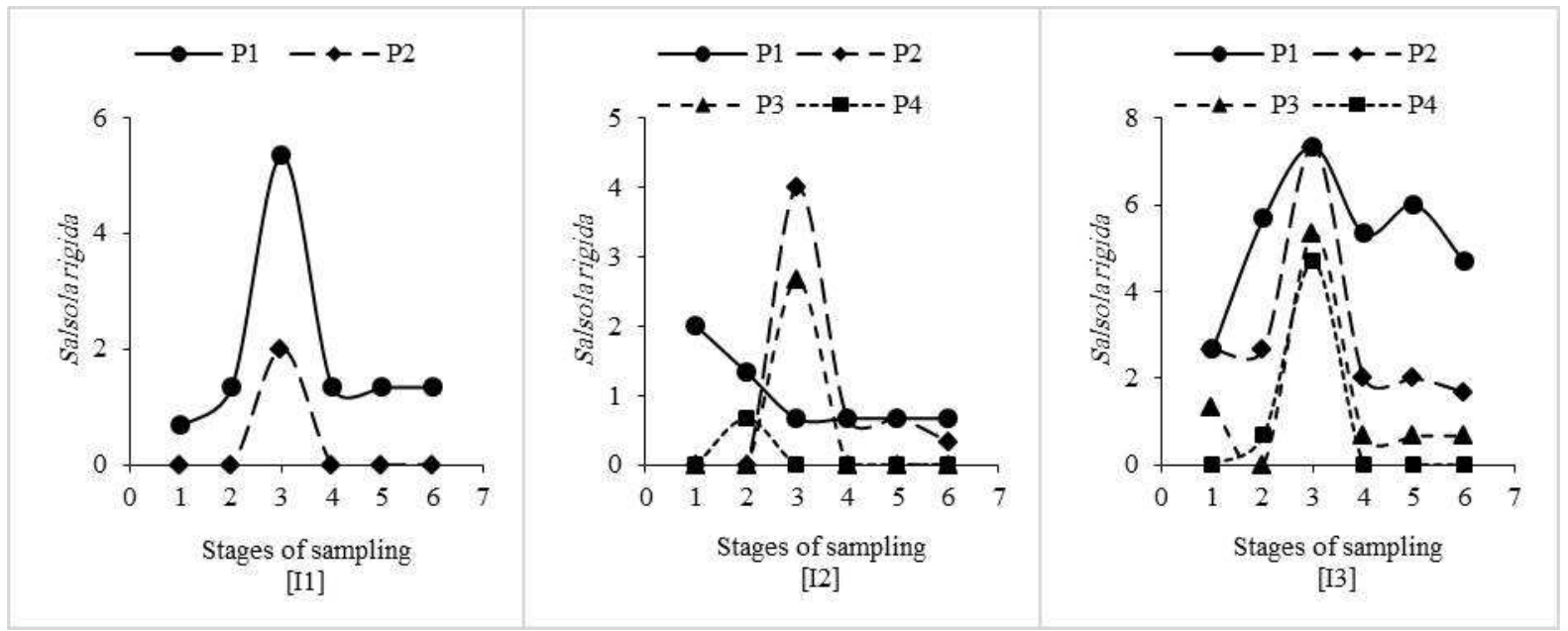

Fig. 8. Salsola rigida community in response to different levels of pumice application and water stress.

I1, I2 and I3: $100 \%, 70 \%$ and 50\% water requirement calculated from class A pan, respectively.

P1, P2, P3 and P4: control, 30, 60 and 90 tons per ha. 


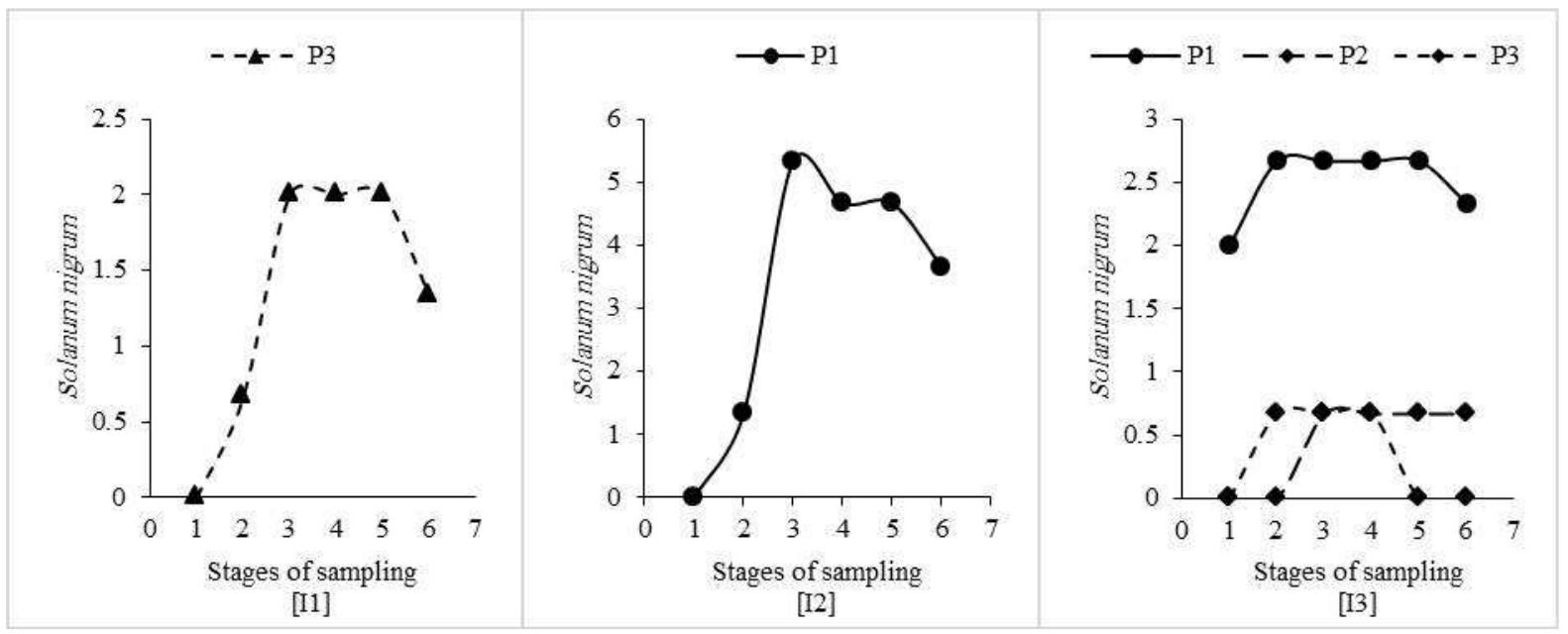

Fig. 9. Solanum nigrum community in response to different levels of pumice application and water stress.

I1, I2 and I3: $100 \%, 70 \%$ and $50 \%$ water requirement calculated from class A pan, respectively.

P1, P2, P3 and P4: control, 30, 60 and 90 tons per ha.

TABLE I.

Fresh and Dry Weight of SOME WeEd SPECIES in RESPONSE to DifFERENT LeVELS of PuMice APPLICATION.

\begin{tabular}{|c|c|c|c|c|c|c|c|c|}
\hline \multirow{2}{*}{$\begin{array}{c}\text { Species } \\
\text { Treatm. }\end{array}$} & \multicolumn{3}{|c|}{ Fresh weight } & \multicolumn{2}{c|}{ Dry weight } \\
\cline { 2 - 8 } & Ch. album & $\begin{array}{c}\text { A. } \\
\text { retroflexus }\end{array}$ & S. viridis & S. irio & S. rigida & \multirow{2}{*}{ Ch. album } & A.restiflexus & S. viridis \\
\hline P1 & $67.69 \mathrm{a}$ & $96.60 \mathrm{a}$ & $64.55 \mathrm{a}$ & $11.01 \mathrm{a}$ & $6.60 \mathrm{a}$ & $19.86 \mathrm{a}$ & $22.39 \mathrm{a}$ \\
\hline $\mathrm{P} 2$ & $45.94 \mathrm{~b}$ & $40.00 \mathrm{~b}$ & $36.62 \mathrm{~b}$ & $3.80 \mathrm{~b}$ & $2.47 \mathrm{ab}$ & $12.61 \mathrm{~b}$ & $9.83 \mathrm{~b}$ & $9.36 \mathrm{~b}$ \\
\hline P3 & $6.29 \mathrm{c}$ & $17.68 \mathrm{~b}$ & $15.20 \mathrm{c}$ & $1.44 \mathrm{~b}$ & $0.23 \mathrm{~b}$ & $1.54 \mathrm{c}$ & $4.77 \mathrm{bc}$ & $6.08 \mathrm{bc}$ \\
\hline P4 & $4.60 \mathrm{c}$ & $5.59 \mathrm{~b}$ & $3.85 \mathrm{c}$ & $1.37 \mathrm{~b}$ & $0.00 \mathrm{~b}$ & $0.84 \mathrm{c}$ & $1.19 \mathrm{c}$ & $1.19 \mathrm{c}$ \\
\hline
\end{tabular}

Different letters in each column for each factor indicate significant difference at $\mathrm{P} \leq 0.05$. P1, P2, P3 and P4: control, 30,60 and 90 tons per ha.

TABLE II.

FRESH and DRY WEIGHT of SOME WEED SPECIES in RESPONSE to DIFFERENT LEVELS of WATER STRESS.

\begin{tabular}{|c|c|c|c|}
\hline \multirow{2}{*}{ Species } & \multicolumn{2}{|c|}{ Fresh weight } & Dry weight \\
\cline { 2 - 4 } Treatm. & Ch. album & S. viridis & A. retroflexus \\
\hline I1 & $39.60 \mathrm{a}$ & $18.38 \mathrm{~b}$ & $13.63 \mathrm{a}$ \\
\hline I2 & $25.43 \mathrm{~b}$ & $42.72 \mathrm{a}$ & $11 \mathrm{a}$ \\
\hline I3 & $28.35 \mathrm{~b}$ & $29.06 \mathrm{ab}$ & $4.05 \mathrm{~b}$ \\
\hline
\end{tabular}
Different letters in each column for each factor indicate. Significant difference at $\mathrm{P} \leq 0.05$.
I1, I2 and I3: $100 \%, 70 \%$ and 50\% water requirement calculated from class A pan.

\section{CONCLUSIONS}

In this research we found that water stress and pumice applied to the soil surface could affects weed distribution. Obtained results showed some weeds in this research was affected by water stress. Weeds such as Chenopodium album appeared sensitive to water stress (Fig. 1) while Amaranthus retroflexus (Fig. 2) and Solanum nigrum (Fig. 8) were neutral to water stress. Also, Amaranthus retroflexus (Fig. 2), Cardaria draba (Fig 3), Setaria viridis (Fig 4), Sisymbrium irio (Fig 5), Xanthium strumarium (Fig 6), Convolvulus arvensis (Fig 7) and Salsola rigida (Fig 8) were resistance to water stress. Weeds are more competitive than the corn to water stress $[14,15]$. In water-limited environments, weeds may have higher leaf water potential than crop, this fact revealed that a water limitation in soil would benefit for weeds more than the crop [16].
Different weed species had different response to pumice application. Chenopodium album (Fig. 1) as sensitive species to water stress and Salsola rigida (Fig. 8) as resistance species to water stress positively affected by pumice application especially under water stress condition. As well as, pumice application had no effect on this weed species under optimal water condition. Amaranthus retroflexus (Fig. 2), Xanthium strumarium (Fig. 6) and Convolvulus arvensis (Fig. 7) were positively affected by pumice application under optimal and limited water conditions. In contrast, Cardaria draba (Fig. 3), Sisymbrium irio (Fig 5) and Solanum nigrum (Fig 9) were negatively affected by under water stress but pumice application had positive effect on community of these species under well watering conditions.

Water limitation can affect any plant processes, such as membrane conformation, chloroplast conformation and 
enzyme activity at cellular level as well as the growth and yield reduction in the whole plant [17]. In this research water stress reduced fresh weight of Chenopodium album and Setaria viridis and dry weight of Amaranthus retroflexus (Tab. 2). Negative effects of pumice on fresh and dry weight of Chenopodium album, Amaranthus retroflexus, Setaria viridis and fresh weight of Sisymbrium irio and Salsola rigida attributed to increasing water availability for these weed species (Tab 1). These weed species may be increasing root development and increasing water absorption and consequently fresh and dry weight improved.

\section{REFERENCES}

[1] FAO, "Food Agriculture Organization of the United Nations, FAO , Information system on water and agriculture," Rome, Italy, 1997.

[2] D. Mazaheri, and N. Majnoun-Hosseini, "Fundamental of agronomy," (4th ed), Tehran University Publication, 2005. (In Persian).

[3] R. Hayat, and S. Ali, "Water absorption by synthetic polymer (Aquasorb) and its effect on soil properties and tomato yield," Int J Agric Biol, 6: 998-1002, 2004.

[4] F. Akbal, "Sorption of phenol and 4-chlorophenol on to Pumice treated with cationic surfactant," J Environ Manage, 74: 239-244, 2004.

[5] M.A. Segura-Castruita, "Escalas de observación en los estudios de génesis de suelos: caso de los suelos de humedad residual," Tesis de Doctorado, Colegio de Postgraduados, Montecillo, México, 2003.

[6] M.A. Segura-Castruita, M.C. Gutiérrez -Castorena, C.A. OrtizSolorio, and P. Sánchez-Guzmán, "Régimen de humedady clasificación de suelos pomáceos del Valle Puebla-Tlaxcala, Terra Latinoamericana, Vol. 23: 13-20, 2005.

[7] M.A. Segura-Castruita, P. Preciado- Rangel, G. González-Cervantes, J.E. Frías-Ramírez, G. García- Legaspi, J.A. Orozco-Vidaly and M.
Enríquez-Sánchez, "Adición de material pomáceo a sustratos de arena para incrementar la capacidad de retención de humedad," Interciencia, Vol. 33: 923-928, 2008.

[8] M. Forouzani, and E. Karimi, "Agricultural water poverty index and sustainability. Agronomy for Sustainable Development," Agronomy for Sustainable Development, Vol. 31: 415-431, 2011.

[9] S.A. Khadem, M. Galavi, M. Ramrodi, S.R. Mousavi, M.J. Rousta, and P Rezvani-moghadam, "Effect of animal manure and super absorbent polymer on corn leaf relative water content, cell membrane stability and leaf chlorophyll content under dry condition," Aust J Crop Sci., 4: 642-647, 2010.

[10] J. Woodhouse, M.S. Johnson, "Effect of super absorbent polymers on survival and growth of crop seedlings," Agric Water Manage., 20: 63-70, 1991.

[11] M.S. Johnson, C.D. Piper, "Cross-linked water storing polymers as aids to drought tolerance of tomatoes in growing media," $\mathrm{J}$. Agron Crop Sci., 178: 2-27, 1997.

[12] M.S. Johnson, "Effect of soluble salts on water absorption by gel-forming soil conditioners," J Sci Food Agric., 35: 1063-1066, 1984.

[13] S. Hassannejad and S. Porheidar Ghafarbi, "Weed flora survey in alfalfa (Medicago sativa L.) Fields of Shabestar (northwest of Iran)," Archives of Agronomy and Soil Science, 971-991, 2013.

[14] T.L. Setter, "Transport/harvest index: Photosynthate partitioning in stressed plants. Plant Biology," Vol.12. Stress responses in plants: Adaptation and acclimation mechanisms. (Ed. by. Ruth G.Alscher, Jonathan R. Cumming). pp. 17-36. Wiley-Liss, U.S.A., 1990.

[15] R.M.M. Crawford, "Studies in plant survival: Ecological case histories of plant adaptation to adversity," Studies in Ecology, Vol. 11. Pp.177-202. Blackwell Scientific publications, Oxford, 1989.

[16] J.D. Timpa, J.J. Burke, J.E. Quisenberry, and C.W. Wendt, "Effects of water stress on the organic acid and carbohydrate compositions of cotton plants," Plant Physiol., 82: 724-728, 1986.

[17] N. Dogan, and S. Akınc1, "Effects of water stress on the uptake of nutrients by bean seedlings (Phaseolus vulgaris L.) Fresen,"Environ. Bull., 20 (8a): 2163-2173, 2011. 